\title{
When Institutions Matter: CAPES And Political SCIENCE IN BRAZIL
}

\author{
Cuando las instituciones importan: CAPES y la ciencia política \\ en Brasil
}

\author{
ANDRÉ MARENCO \\ Universidade Federal do Rio Grande do Sul
}

\begin{abstract}
The purpose of this paper is to analyze the institutional evaluation processes applied to Brazilian graduate programs, which processes are carried out by a federal agency, CAPES (Coordenação para o Aperfeiçoamento de Pessoal de Nível Superior/Coordination for the Advancement of Graduate Education), and their impact on the development of Political Science in Brazil. To do that, the text is divided into four parts: the first section presents CAPES' characteristics and evolution in the past 60 years. The second part describes the academic evaluation procedures graduate programs are submitted to by CAPES for them to enter or remain in the system. Next, we analyze the influence of evaluation rules and criteria set by CAPES on the development of Political Science in Brazil. Finally, the last section examines the relationships between the institutional evaluation results, in the form of scores assigned to graduate institutions, and CAPES' funding patterns in order to determine to what extent a relationship between performance and grants can be isolated.
\end{abstract}

Key words: Political science, institutional evaluation, academic institutions, scientific production

\section{RESUMEN}

El objetivo de este trabajo es analizar los procesos de evaluación institucional de posgrado en Brasil, realizado por una agencia federal, CAPES (Coordinación de Perfeccionamiento del Personal de Nivel Superior), y su influencia en el desarrollo de la ciencia política en Brasil. Para ello, el texto se divide en cuatro partes: en la primera sección hemos tratado de presentar las características de la CAPES y su evolución en los últimos 60 años. En la segunda parte son reconstituidos los procedimientos de evaluación académica sometidos a los cursos de posgrado por la CAPES, para entrar o permanecer en el sistema. Después, se intenta analizar la influencia de las normas y criterios de evaluación establecidos por la CAPES en el desarrollo de la ciencia política en Brasil. Finalmente, se busca desentrañar la relación entre los resultados de la evaluación institucional en forma de notas otorgadas a las instituciones de posgrado y las modalidades de financiación a cargo de la CAPES, buscando delimitar la medida en que pueda ser aislado una relación entre el rendimiento y la asignación de recursos financieros.

Palabras clave: Ciencia Política, evaluación institucional, instituciones académicas, producción científica. 


\section{CAPES AND BRAZILIAN GRADUATE EDUCATION}

The Brazilian graduate education system operates based on the combination of accreditation, evaluation, and funding activities carried out by a federal agency, CAPES (Coordenação para o Aperfeiçoamento de Pessoal de Nivel Superior/Coordination for the Advancement of Graduate Education). CAPES was created in 1951 as a "National Campaign for the Advancement of Graduate Education," included in a development-oriented agenda pursued during the second administration of Getúlio Vargas (1950-54). The streamlining and professionalization of public administration and the need to train experts to face the country's development and industrialization demands encouraged the creation of a federal agency dedicated to the advancement of graduate personnel. The agency's first actions included hiring foreign visiting professors, exchange and cooperation between Brazilian and international universities, granting scholarships, and promoting scientific events. After the authoritarian regime took power in 1964, CAPES no longer reports directly to the Office of the President of the Republic and is taken over by the Ministry of Education.

In 1965 the first graduate programs are created: 27 Master's and 11 doctoral programs. That same year, Opinion 977/65 set the rules for the organization of Brazil's graduate education system. Since 1976, CAPES has conducted periodic evaluations of the graduate programs operating in the country. In 2007, the National Congress passed a law expanding CAPES' responsibilities to also task the agency with fostering the training of basic education teachers.

Brazilian graduate education comprises three types of programs: doctoral (PhD), Academic Master's (MA), and Professional Master's (MA Prof). The main difference between academic and professional Master's programs lies in the future degree holders' profile: an academic researcher or a professional who has technical knowledge applied to the needs of companies or the public administration. Professional Master's is the most recent type and the first programs date from 1998. By the end of 2012, there were 1,717 doctoral, 2,894 Academic Master's, and 395 Professional Master's programs.

The evolution of the Brazilian graduate education system is shown in Figure 1.

We see a basically continuous upward line regarding the number of doctoral, Master's, and Professional Master's programs. There are no breaks or shifts in this pattern that may be associated to political or institutional changes. We see no pattern breaks after 1985, when the military regime gave way to civilian governments. Nor can the seven administrations held by five different Presidents of the Republic be told apart through substantial changes along the expansion of the Brazilian graduate education system. Despite the changes to political regimes or the substitution of governments taking place in the period, the number of graduate programs has constantly increased, indicating that graduate education has taken the shape of a State policy.

Another particular element in the Brazilian case is that several procedures that monitor and maintain the graduate education system are carried out by a single agency. CAPES is responsible for (1) accrediting the Institutions so they may legally grant Master's 
Figure 1. Evolution of the Brazilian Graduate Education System

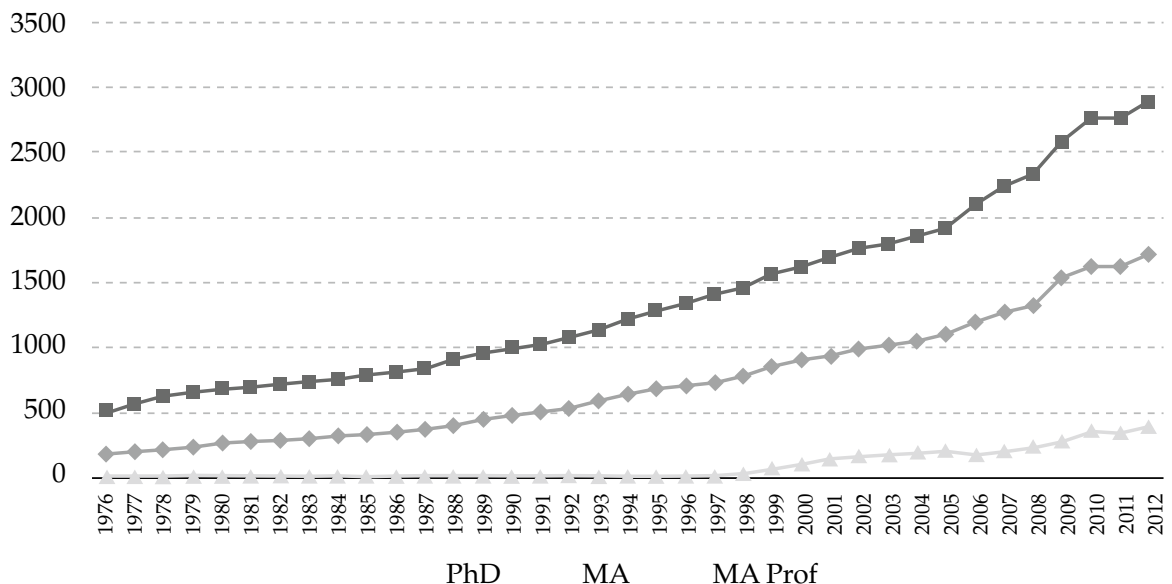

Source: CAPES.

and doctoral degrees; (2) periodically evaluating their performance, compliance with minimum quality requirements, and achievement of international excellence standards, and (3) funding a significant portion of the system by granting scholarships and financing the accredited graduate programs.

\section{CAPES AND THE INSTITUTIONAL EVALUATION OF BRAZILIAN GRADUATE EDUCATION}

Today, both new program and triennial evaluations are conducted regarding 48 areas of knowledge, ${ }^{1}$ on which preliminary analyses are carried out and opinions are issued and forwarded to the Higher Education Technical Scientific Council (Conselho TécnicoCientífico da Educação Superior - CTC-ES). The Council decides on parameters and criteria and also on the scores assigned to Programs. ${ }^{2}$ Scores range from 1 to 7 . Three is the minimum score for a Program to begin or remain operating, while 6 and 7 are assigned to Institutions whose performance is equivalent to that of international centers of reference.

In Brazil, only Master's and doctoral degrees conferred by CAPES-approved programs and subsequently ratified by the National Board of Education are valid. Therefore, all programs must undergo CAPES' accreditation process so they may operate legally and grant graduate degrees.

This process comprises a strict procedure for entering the system, when the technical and academic merits of new program projects go through different evaluation stages.

1 A list of the 48 areas of knowledge operating in 2013 can be found at http:/ /www.capes.gov.br/avaliacao/ areas-paginas

2 For the duties and makeup of CTC-ES, see http://www.capes.gov.br/sobre-a-capes/ctc 
In addition to fulfilling legal and technical requirements, every new graduate program must prove it sufficiently meets a set of criteria dedicated to assessing the future program's quality:

- The permanent faculty's scientific productivity, according to the required parameters set for each area of knowledge and measured via publications classed according to a ranking of journals, scientific periodicals, and books;

- Previous experience of faculty connected to the proposed program in teaching doctoral and Master's candidates and undergraduate students; number of faculty members who are the $\mathrm{CNPq}$ 's $\mathrm{PQ}$ researchers as an indicator of their regular scientific research activities;

- Program design consistency, considering the alignment between its thematic focus and courses, thematic specialization fields, research projects, and faculty profile;

- Availability of proper infrastructure equipped with research labs, databanks, libraries, equipment, suitable research software, and evidence of the Institution's commitment to the viability of the future program's project.

The fulfillment of these requirements is evaluated in two stages: first, a Committee staffed by ad hoc consultants on the respective area of knowledge and two members from other academic areas issues an opinion about the project's viability and compliance with the minimum requirements; second, CAPES' Technical Scientific Council comprising members from the Humanities and Exact and Biological colleges analyzes each of the proposals submitted, considers the opinion from the respective area of knowledge, and makes a final decision. In 2014, approximately 657 new program proposals were submitted, of which 200 were approved, corresponding to a $30.4 \%$ approval rate.

CAPES periodically evaluates all graduate education system-accredited programs regarding their performance ${ }^{3}$ and assigns scores corresponding to indicators related to their scientific production, ability to train Masters and Doctors, degree of internationalization, publications by candidates, social insertion. ${ }^{4}$ The core of the Brazilian graduate education system's evaluation can be isolated in the combination between (i) scientific production -as proxy of academic quality and vocation for research- (ii) education of Masters and, above all, Doctors, and (iii) internationalization achieved by each program. Under the 2013 Triennial Evaluation Regulations, the maximum score of 7 must be reserved for Institutions showing "a level of performance (education of Doctors and intellectual production) much higher than other programs in the area; and performance equivalent to that of international centers of excellence in the area (internationalization and leadership)" ${ }^{5} \mathrm{~A}$ top Institution is expected to have great Doctor training capabilities.

3 For general criteria used in the 2013 Triennial Evaluation, see https://docs.google.com/ viewer?a=v\&pid=sites\&srcid=Y2FwZXMuZ292LmJyfHRyaWVuYWwtMjAxM3xneDozODgxYTU2NTA1MzAyMjI3

4 For criteria adopted by the Political Science and International Relations department in the 2013 Triennial Evaluation, see Comittee Document, http://www.capes.gov.br/images/stories/download/avaliacaotrienal/ Docs_de_area/CI\%C3\%AAncia_Pol\%C3\%ADtica_doc_area_e_comiss\%C3\%A3o_21out.pdf

5 Regulations for the 2013 Triennial Evaluation (2010-2012)", p. 7 at https://docs.google.com/ viewer?a=v\&pid=sites\&srcid=Y2FwZXMuZ292LmJyfHRyaWVuYWwtMjAxM3xneDozODgxYTU2NTA1MzAyMjI3 
The quality required from such education is indirectly gauged considering the faculty's vocation for research and confirmed by a high frequency of publications per faculty member in periodicals ranking high on Qualis (see below) and/or high-ranking books and indicators showing a performance equivalent to that of the main international institutions dedicated to the area.

For a program to score 7 -the highest score in the system- it must show an academic performance equivalent to that of international centers of excellence in the area of study, indicators considerably above those of others programs in the same area with respect to scientific production and ability to educate Doctors, and obtain a "very good" score in all evaluation criteria and items. ${ }^{6}$ Hence, scores of 7 are a reference for an institution's degree of internationalization and acknowledge its position as an academic leader among the international academic community.

Although scientific publication is not the only factor in the evaluation of graduate schools' performance, it provides a suitable measurement of their vocation for academic research and the international visibility of the production turned out by Brazilian researchers. To rank the scientific production of graduate programs, periodicals are previously classed in a ranking called Qualis, according to 8 strata (A1, A2, B1, B2, B3, B4, B5, and C) based on criteria that vary in each area: impact factor, indices, internationalization, qualitative criteria. In the area of Political Science, only publications in periodicals rated A1, A2 and B1 are considered for purposes of assigning scores to academic production, and the requirements for an area to include a journal in such strata are the impact factor (for foreign periodicals) and inclusion in the Scopus (for A1 and A2) and Scielo (for B1) ${ }^{7}$ bases.

Two objections have been raised against the inductive effect CAPES' evaluation has had on how Brazilian graduate education is institutionalized. The first is that the institutional evaluation rules would encourage "productivism." By prioritizing quantitative indicators, such as the number of papers published, citations, or impact factor, CAPES' institutional evaluation would end up encouraging scientific production quantity over its quality or originality, besides prompting the use of subterfuges to artificially increase those rates, such as self-citation, cross referencing, or replication of the same production (Bianchi, 2014). A second objection points out that the academic institutionalization would lead to a drop in the creation of relevant knowledge and to a homogenized scientific production. As production quantity is pursued and the publication of papers in scientific journals instead of as books is prioritized, the outcome would be disciplines institutionalized in a manner that leads to partial, ultra-specialized, limited-scope results to the detriment of long-term research and the construction of "major theories" and comprehensive explanations (Brandão, 2007).

One may credit a significant portion of these objections to a lack of information about the parameters conventionally used in the academic evaluation process and responsible 
for a discipline's institutionalization (Altman, 2012). While "institutionalization" may be understood as the establishment of a field furnished with its own rules, values, and hierarchy, the institutionalization of political science as a discipline would mean that the values that determine professional recognition and status do not derive from the consent of entities such as the "public opinion" (in the form of social popularity) or the typical deference of other social categories such as law, journalism or literature and their high regard for rhetoric, proselytism, or illustrated essay-writing, but from the discipline's own codes and parameters for treating "politics as a science" (Skinner, 1978; Sartori, 1984; Barry, 1996; Von Beyme, 1996; Dogan, 1996; Bulcourf, 2004).

Contrary to what its critics allege, the institutional evaluation of graduate education prizes precisely its quality and downplays the importance of quantity regarding scientific production. That is made clear by the creation of the Qualis system, in charge of setting a scientific production quality ranking based on criteria specific to each area of knowledge but which have peer recognition as their shared feature: impact factor gauged by means of citations (that is, the importance assigned to an author's contribution by said author's scientific peers), strictness and selection of the peer review procedures adopted by each periodical for accepting papers, and even more subjective criteria such as the importance assigned to a journal within a given field of study. For purposes of evaluating the institutional performance of Brazilian graduate education, producing a few articles published in periodicals rated at the higher strata (and therefore with greater citation potential, acceptance rigor, or recognition in the discipline's community) is worth more than a large amount found in periodicals rated at the lower strata of Qualis. Hence, quality -gauged via different procedures that measure peer judgment and recognitionstands indisputably above scientific production quantity when it comes to academic evaluation and institutionalization. ${ }^{8}$

\section{ACADEMIC EVALUATION AND BRAZILIAN POLITICAL SCIENCE}

Parallel to the expansion of Brazilian political science, we find a significant consolidation in academic consistency rates in the last two triennials, which proves that growth and quality are not mutually exclusive. The position of the Political Science and International Relations areas in the citation ranking by SCImago Journal \& Country Ranking rose from 38th in 2004 to 16th in the world in 2012. Until 2004, they ranked behind Argentina, Chile and Mexico in terms of publications indexed in Latin America. Since 2008, Brazil has secured a leadership position in Latin American PS \& IR, considering SCImago data on documents and citations. ${ }^{9}$

One angle from which to understand where publications in the area are directed to is to compare the distribution of periodicals per Qualis stratum with the distribution of

8 In that regard, see the Political Science and International Relations Department Document at http://www. capes.gov.br/images/stories/download/avaliacaotrienal/Docs_de_area/CI\%C3\%AAncia_Pol\%C3\%ADtica_ doc_area_e_comiss $\%$ C3\%A3o_21out.pdf

9 See http://www.scimagojr.com/countryrank.php 
the total production in the triennial. We may interpret that a production in the upper strata below the proportional offer of places to publish would indicate a lower quality in the profile of publications; conversely, an area's concentration in the upper strata (A1, $\mathrm{A} 2$ and B1) above the proportional offer of journals rated at these strata would indicate a collective effort to direct the publication of scientific production towards outlets that have greater impact and stricter paper selection criteria. That is shown by the data in the figure below:

Figure 2. Scientific production - Qualis strata versus publications

QUALIS DPROD 10/12

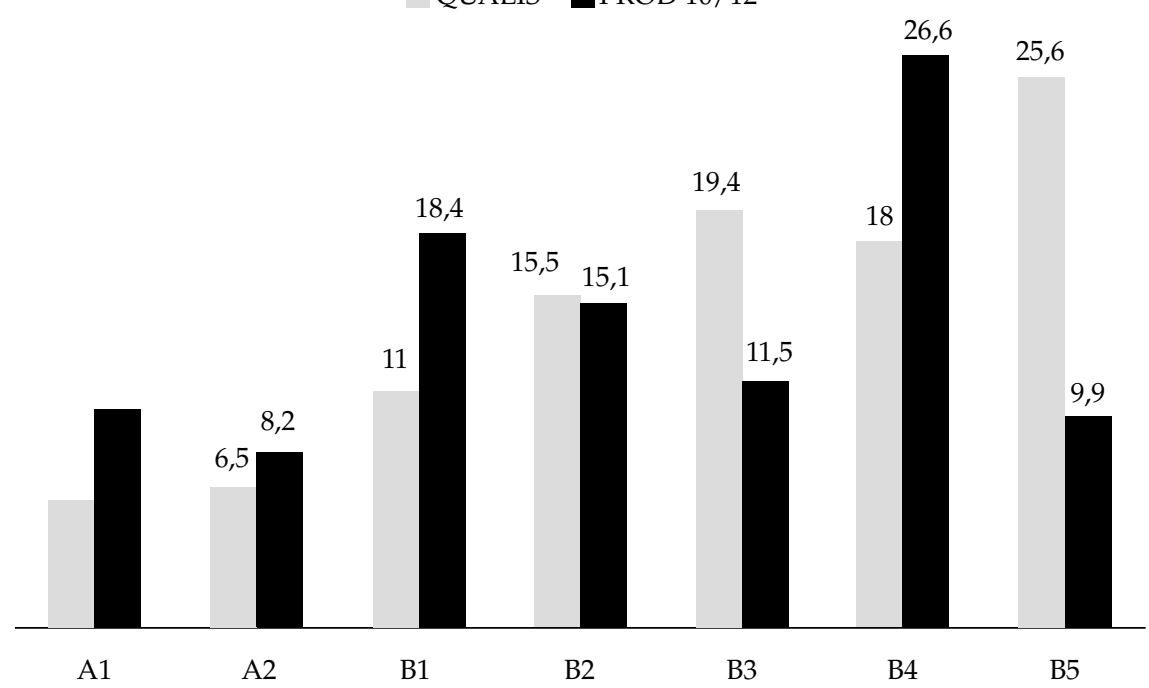

Source: CAPES.

First of all, the data show that a little over a third of the entire production by the area's permanent faculty was concentrated in the A1, A2 and B1 strata. Moreover, the total production in these strata exceeded the offer of potentially publishable places, defined by the distribution in Qualis strata.

The Figure below shows the results for the 2013 Triennial Evaluation of Brazilian graduate education, considering the distribution of scores obtained by graduate programs in the areas of Political Science and International Relations and a comparison with such distribution regarding all 48 areas of knowledge. Considering all evaluation criteria scientific production, human resource training, international collaboration- the following scores are assigned: 1 (insufficient), 2 (poor), 3 (regular), 4 (good), 5 (very good), 6 and 7 (excellent). To remain in the system and continue issuing legally valid diplomas, a program must obtain a minimum score of 3 (Master's) or 4 (doctoral). 
Figure 3. 2013 Triennial Evaluation - Compared distribution of scores between Political Science and the Graduate Education System in Brazil

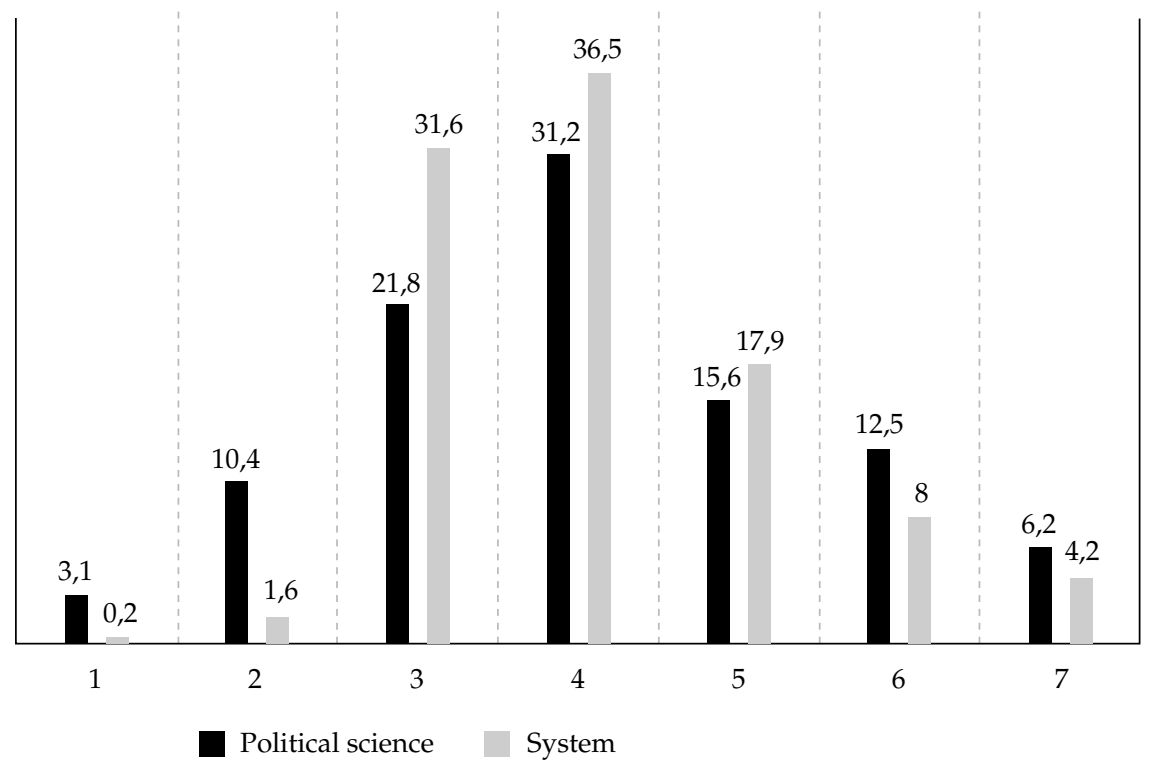

Source: CAPES.

The distribution of scores assigned to Brazilian Political Science graduate programs in 2013 was similar to a Gauss Curve, with the mode in central positions and two residual tails at the ends. Compared to the behavior of scores assigned to the whole of the system, we find a greater concentration at the ends of Institutions scoring 1 and 2, which were consequently shut down for poor quality, as well as a slightly higher ratio at the upper strata comprising scores of 6 and 7.

In order to measure the consistency of the association between the main indicators used in the evaluation and the scores assigned, we performed a statistical test based on multivariate regression. As regressors, we used two rates to measure scientific production: the Rate of Qualified Production in journals (IPQ-r) and the Rate of Qualified Productionbibliographical (IPQ-1). To evaluate the proficiency of doctoral programs, we used the Rate of Doctors per capita (IDO). The dependent variable was the scores obtained by the programs in the 2010/2013 Triennial Evaluation. We expected there would be a strong correlation and that the rates of scientific productivity (IPQ-r and IPQ-1) and doctor training (IDO) would be highly capable of predicting the variations seen in the programs' scores. The results are shown below: (Table 1)

It can be said that scores are strongly associated with the programs' performance in the criteria of productivity and degrees held by faculty, as gauged via the indicators used in the 2013 Evaluation. The adjusted $\mathrm{R}^{2}$ was 0.808, which means the [IPQ- ${ }^{*}$ IPQ- ${ }^{*}$ IDO] model makes it possible to account for over $80 \%$ of the variation found in the scores. 
Table 1. Linear regression-production and thesis indicators versus scores

\begin{tabular}{cccc}
\hline $\mathrm{R}$ & $\mathrm{R}^{2}$ & $\mathrm{R}^{2}$ adjusted & Standard error of estimate \\
\hline 0.909 & 0.827 & 0.808 & 0.65 \\
\hline
\end{tabular}

Regressors: (constant), IPQ-r, IPQ-1, IDO.

\begin{tabular}{lccccc}
\multicolumn{5}{c}{ ANOVA } \\
\hline Model & Sum of squares & df & Mean squares & F & Sig \\
\hline Regression & 56.117 & 3 & 18.706 & 44.543 & .000 \\
Residual & 11.758 & 28 & 0.420 & & \\
Total & 67.875 & 31 & & & \\
\hline
\end{tabular}

Regressors: (constant), IPQ-r, IPQ-1, IDO.

Dependent Variable: Scores.

Coefficients

\begin{tabular}{|c|c|c|c|c|c|}
\hline \multirow[t]{2}{*}{ Model } & \multicolumn{2}{|c|}{$\begin{array}{l}\text { Non-standardized } \\
\text { coefficients }\end{array}$} & \multirow{2}{*}{$\begin{array}{c}\begin{array}{c}\text { Standardized } \\
\text { coefficients }\end{array} \\
\text { Beta }\end{array}$} & \multirow[t]{2}{*}{$\mathrm{T}$} & \multirow[t]{2}{*}{ Sig } \\
\hline & B & Standard error & & & \\
\hline (Constant) & 2.691 & .172 & & 15.673 & .000 \\
\hline IPQ-r & 8.785E-03 & .002 & .510 & 4.822 & .000 \\
\hline IDO & .587 & .191 & .322 & 3.071 & .005 \\
\hline IPQ-1 & .508 & .259 & .218 & 1.961 & .060 \\
\hline
\end{tabular}

Particularly, the Rate of Qualified Production-journals (IPQ-r) shown a strong predictive power and was statistically significant at $1 \% .^{10}$

\section{CAPES: GRADUATE EDUCATION EVALUATION VERSUS FUNDING}

In addition to accreditation and evaluation, CAPES plays an important role when it comes to funding the Brazilian graduate education system. Besides Capes, other federal and state agencies also provide significant funds for research and graduate education, such as the National Science and Technology Development Council (Conselho Nacional de Desenvolvimento Cientifico e Tecnológico-CNPq) and the State Research Support Foundations (Fundações Estaduais de Apoio à Pesquisa-FAPs) operating in most of the 26 Brazilian states. As shown by the data in the chart below, CAPES' budget shot up and increased nearly 10-fold in a decade between 2004 and 2013 to reach the significant amount of USD 2.03 
billion spent that year. By comparison, CNPq spent USD 816 million of its budget in 2013, approximately $60 \%$ less than CAPES.

Figure 4. CAPES budget, in USD billion

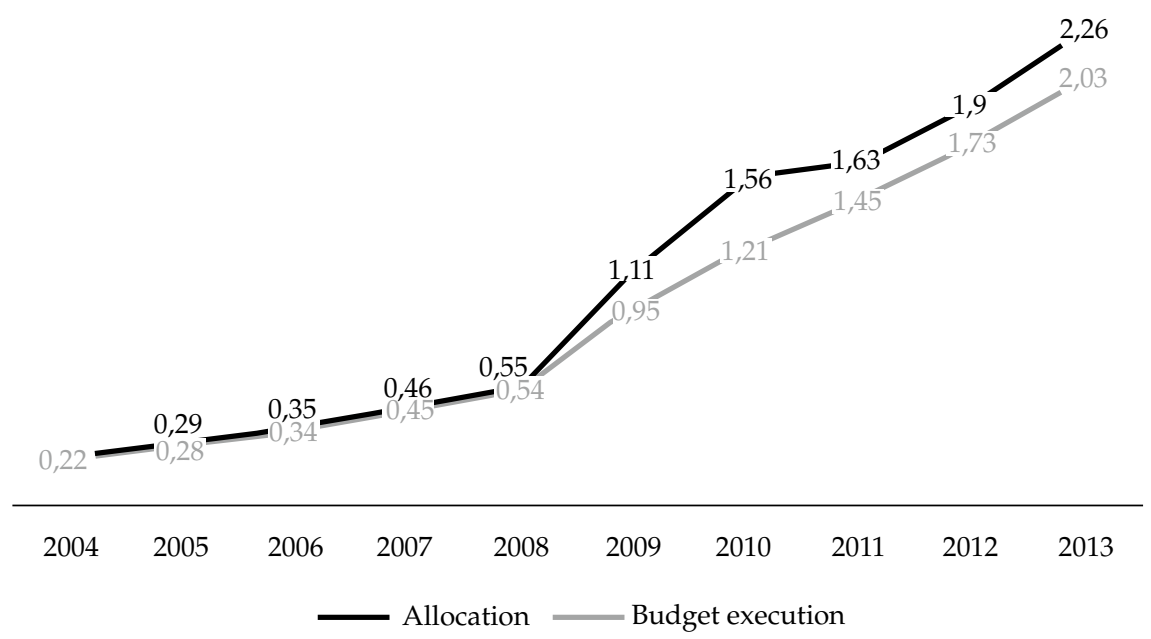

Source: CAPES.

Approximately $84.5 \%$ of CAPES's budget is allocated to Master's and doctoral grants in Brazil and abroad. ${ }^{11}$ Graduate education development activities, such as funds provided to Institutions, funding for holding or attending scientific events, support for academic cooperation and exchange networks represent about $4.1 \%$ of the budget. Expenses with the agency's personnel amount to merely $1.4 \%$ of its resources. ${ }^{12}$

In 2012, CAPES awarded 27,600 doctoral grants, 46,500 Master's grants, and 3,700 postdoctoral grants. Considering how important the grants awarded to candidates are in terms of the budget and the graduate education support policy implemented by CAPES, we must look into the criteria set for the distribution of these resources between the institutions and the performance evaluation results' impact on their allotment. To that end, we need to compare the triennial evaluation results with the grant award data for the following triennial period. To do that, we chose to take the scores assigned in 2010 and compare them with the information on grants for the 2010-2012 triennial. By so doing, we were able to gauge the performance evaluation's impact on the distribution of funds in the period immediately following.

11 The monthly amount of doctoral grants in Brazil is approximately USD 850; a Master's candidate in Brazil gets USD 585, and grants for doctoral studies abroad amount to USD 1,300 .

12 http://capes.gov.br/images/stories/download/sobre/Orcamento_2004-2013_tabela.pdf 
First of all, we should consider the regulations set for the distribution of funds and grants. In the 2010/12 period, the main regulatory resolutions regarding grant awards were Ordinances nos. 64 and 76, respectively enacted on March 24 and April 14, 2010.

Ordinance $76^{13}$ specifically regulated the Social Demand Program and set requirements for Institutions to obtain grants (arts. 2 to 5), requirements to be fulfilled by candidates awarded grants (art. 9), and distribution criteria. The distribution of the number of grants for each Institution was laid out in art. 7:

Art. 7. The number of grants will be defined according to the following requirements:

I - policy on priority support for strategic areas established by CAPES;

II - program characteristics, location, size, and performance;

III - most pressing training needs detected in the country, at all times through diagnoses and studies.

Hence, grant funds are distributed based on three factors: definition of strategic areas, institutional performance, and policy fostering the expansion of graduate education in poorer and/or less populated regions (Brazil's Amazon region and states in the North, Northeast, and Center-West). Strategic areas were established based on priorities set by a governmental agenda oriented to critical sectors for the country's development, such as the various branches of engineering, technology innovation, public health etc., which in a way has led to a prevalence of the hard sciences.

In keeping with that goal, Ordinance 64 set a weight chart meant to establish a hierarchy of priorities between the different areas of knowledge (Table 2).

Therefore, technological, biological, agrarian, and healthcare areas benefit from a higher factor when it comes to determining the distribution of funds. This asymmetry is also found in the "Science without Borders Program" launched in 2011 to encourage up to 100,000 Brazilian undergraduate and graduate students to study abroad. By decision of the government, the humanities have been excluded from this Program's grants.

To assess the impact of results from CAPES' graduate program performance evaluation on the distribution of funds for institutions, we chose to isolate the information on performance scores and numbers of grants awarded to the areas of Political Science and International Relations. That has allowed us to highlight the effect of the bias created by the government's strategic priorities by focusing on the relationship between academic performance and funds obtained as grants. In other words, the question to be answered at this point is to what extent the score earned by each institution in the academic performance evaluation carried out in 2010 influenced the number of student grants obtained by Political Science and International Relations graduate programs in the following three years $(2010 / 2011 / 2012)$. 
Table 2. Priority areas of knowledge, as per the weights assigned

\begin{tabular}{lcc}
\hline \multicolumn{1}{c}{ Areas } & \multicolumn{2}{c}{ Weights } \\
\cline { 2 - 3 } & Master's & Doctoral \\
\hline Exact Sciences & 4 & 5 \\
Exceptions: & 3 & 4 \\
Mathematics, Statistics & 4 & 5 \\
Biological Sciences & 4 & 5 \\
Engineering & 4 & 5 \\
Health Sciences & & \\
Exceptions: & 3 & 4 \\
Physical Education, Nursing & 4 & 5 \\
Agrarian Sciences & 2 & 3 \\
Applied Social Sciences & & \\
Exceptions: & 3 & 4 \\
Architecture, Communications & 2 & 3 \\
Human Sciences & & \\
Exceptions: & 3 & 4 \\
Psychology & 4 & 5 \\
Anthropology, Geography & 2 & 3 \\
Languages and Linguistics & 3 & 4 \\
Arts & &
\end{tabular}

Source: CAPES.

The chart below compares the scores obtained by each of the 26 programs in place at the time with the Master's and doctoral grants received:

Figure 5. Relationship between evaluation and grant awards

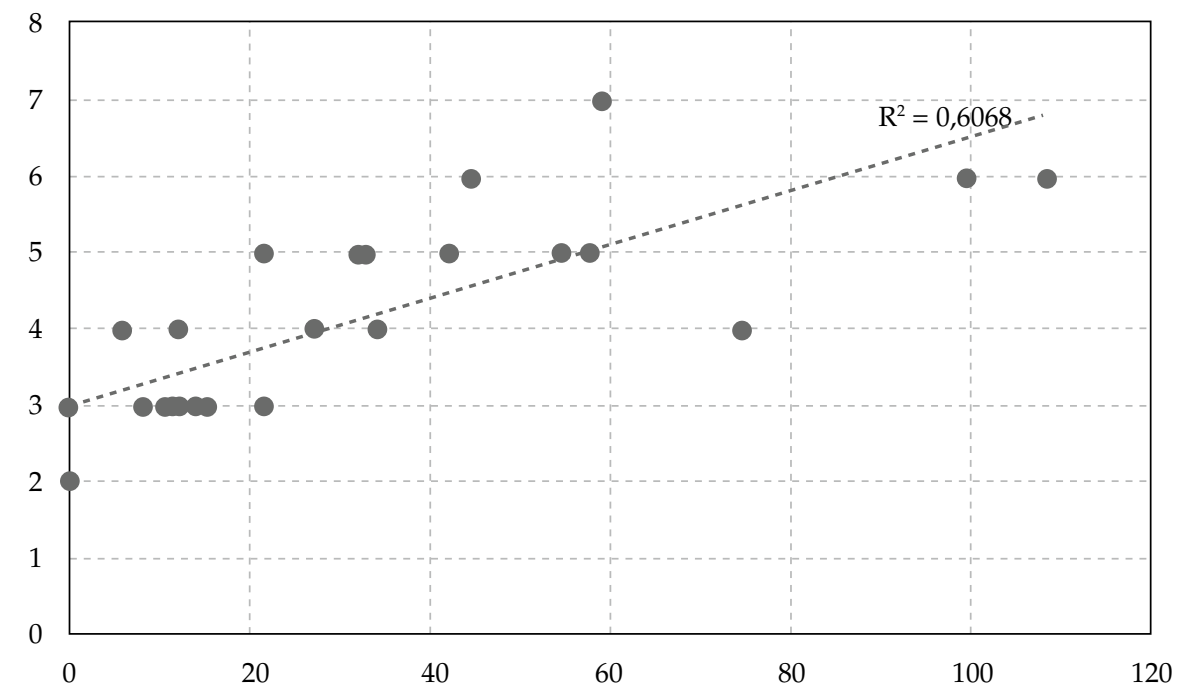

Source: CAPES, http:/ / capes.gov.br/component/content/article/91-conteudo-estatico/avaliacaocapes/6886-geocapes, accessed on January 20, 2015. 
Once we know the scores assigned to academic performance (especially scientific productivity and training of Masters and Doctors), we can predict or explain approximately $60 \%$ of the variation found in the funds distributed to Brazilian political science and international relations graduate programs, which indicates a significant association between these two aspects. Among the factors that lessen the correlation between performance/funds are the following two:

1. Geographic location, as institutions located in less economically and socially developed regions are assigned a quota of grants higher than what may be expected considering their academic performance;

2. Conversely, the top performing program, which scored 7 (University of São Paulo), received a smaller quota of federal funds than one might have expected. However, that may be explained by the number of grants offered by FAPESP (Fundação de Amparo à Pesquisa no Estado de São Paulo/São Paulo State Foundation for Research Support). São Paulo is the wealthiest, most economically developed state in the country. Its state research foundation is renowned for its organization structure and financial income, which supplies part of the demand for research and graduate education funds in the state.

\section{CONCLUSION}

CAPES is a Brazilian federal agency connected to the Ministry of Education and responsible for the accreditation, evaluation, and funding of the Brazilian graduate education system. Brazilian graduate education has developed to a point of becoming a continuously expanding State policy that is not impacted by shifts in governments or political regimes. Since 1976, CAPES has periodically carried out institutional evaluations of the graduate programs operating in the country and assigning them scores based on their faculty's and candidates' scientific production, the training of Masters and Doctors at each Institution, their internationalization, and other assessment criteria.

The influence this institutional evaluation process carried out by CAPES has had on the development of Brazilian Political Science can be seen especially in the increase in scientific production, the orientation and concentration of such production towards more academically prestigious periodicals and journals, and the rising positions achieved by Brazilian PS \& IR in the disciplines' international rankings. At the same time, a comparison between the performance indicators for each institution offering Political Science Master's and doctoral programs in Brazil and the scores obtained in this academic evaluation shows a strong statistical correlation that reveals the consistency achieved by this institutional assessment.

Finally, the comparison between the scores obtained in CAPES's evaluation and the funds granted to the various graduate programs reveals that, although it is not the only or linear fund allocation criterion (priority to technological or biological areas and fostering the expansion of graduate education in less developed regions also influence the transfer 
of funds), we can find a significant association between institutional performance and the offer of funds, especially in the form of research grants.

Indeed, at least when it comes to Brazilian graduate education, institutions do matter, or at least CAPES matters for the university system's makeup at this level.

\section{REFERENCES}

Altman, David. 2012. "Where is Knowledge Generated? On the Productivity and Impact of Political Science Departments in Latin America". European Political Science 11: 71- 87.

Barry, Brian. 1996. "Political Theory, Old and New". In A New Handbook of Political Science, Robert Goodin and Hans-Dieter Klingemann, 531-548. Oxford: Oxford University Press.

Bianchi, Álvaro. 2014. "Avaliação acadêmica: muito além do jardim". In http://blogconvergencia.org/ blogconvergencia/?p=1915 accessed on july, 25th, 2014.

Brandão, Gildo Marçal. 2007. Linhagens do pensamento politico brasileiro. São Paulo: Hucitec.

Bulcourf, Pablo and Juan Cruz Vasquez. 2004. "La Ciencia Política como Profesión". PostData 10, dezembro: 255-304.

Capes. 2013. Documento de Área Ciência Política e Relações Internacionais 2013. Brasília: Capes.

http://www.capes.gov.br/images/stories/download/avaliacaotrienal/Docs_de_area/CI\%C3\%AAncia_ Pol\%C3\%ADtica_doc_area_e_comiss\%C3\%A3o_21out.pdf accessed on July, 25th, 2014.

Dogan, Mattei. 1996. "Political Science and the Other Social Sciences". In A New Handbook of Political Science, Robert Goodin and Hans-Dieter Klingemann, 97-130. Oxford: Oxford University Press.

Marenco, André. 2014. "The Three Achilles' Heels of Brazilian Political Science". Brazilian Political Science Review 8 (3): 3-38.

Sartori, Giovanni. 1984. La Política. México D.F.: Fondo de Cultura Económica.

Skinner, Quentin. 1978. The Foundations of Modern Political Thought. Cambridge: Cambridge University Press.

Von Beyme, Klaus. 1996. "Political Theory: Empirical Political Theory". In A New Handbook of Political Science, Robert Goodin and Hans-Dieter Klingemann, 519-530. Oxford: Oxford University Press.

André Marenco is Coordinator of the Political Science and International Relations Committee at CAPES, member of the Higher Education Technical Scientific Council/CAPES/Ministry of Education, Brazil, and Professor of the Public Policies graduate program at Universidade Federal do Rio Grande do Sul. E-mail: amarenco@terra.com.br 